\title{
Recombinant Fibronectin Fragment III8-10/PLA Hybrid Nanofibers Enhance the Bioactivity of Titanium Surface
}

J. Guillem-Marti ${ }^{1,2, \dagger, *}$, G. Boix-Lemonche ${ }^{1,2, \dagger}$, D. Gugutkov ${ }^{3}$, M.-P. Ginebra ${ }^{1,2,3}$, G. Altankov $^{3,4,5}$, J.M. Manero ${ }^{1,2}$

${ }^{1}$ Biomaterials, Biomechanics and Tissue Engineering Group, Department of Materials Science and Metallurgical Engineering, Universitat Politècnica de Catalunya (UPC), Barcelona, Spain

${ }^{2}$ Barcelona Research Center in Multiscale Science and Engineering, Universitat Politècnica de Catalunya, Barcelona, Spain

${ }^{3}$ Institute for Bioengineering of Catalonia (IBEC), 08028 Barcelona, Spain Centro de Investigación Biomédica en Red en Bioingeniería, Biomateriales y

Nanomedicina (CIBER-BBN), 50018 Zaragoza, Spain

${ }^{5}$ ICREA (Institució Catalana de Recerca i Estudis Avançats), 08010 Barcelona, Spain These authors contributed equally to this work

*Corresponding authors: jordi.guillem.marti@upc.edu 
Aim: Develop a nanofiber-based biomimetic coating on titanium (Ti) that mimicks the complex spatiotemporal organisation of the extracellular matrix (ECM). Methods: Recombinant cell attachment site (CAS) of fibronectin type III8-10 domain was coelectrospun with polylactic acid (PLA) and covalently bound on polished Ti discs. Osteoblast-like SaOS-2 cells were used to evaluate their complex bioactivity. Results: A significant increase of cell spreading was found on CAS/PLA hybrid nanofibers, followed by control pure PLA nanofibers and bare Ti discs. Cell proliferation showed similar trend being about twice higher on CAS/PLA nanofibers. The significantly increased ALP activity at day 21 indicated an enhanced differentiation of SaOS-2 cells. Conclusion: Coating of Ti implants with hybrid CAS/PLA NFs may improve significantly their osseointegration potential.

Keywords: fibronectin $\cdot$ recombinant protein $\cdot$ hybrid nanofibers $\cdot$ PLA $\cdot$ electrospinning - osseointegration 
Although titanium (Ti) is the most widely used material for bone tissue implantation, its lack of bioactivity compromises in some circumstances the stability of implants due to reduced osseointegration rates. Some emerging biomimetic strategies are focused on the grafting of $\mathrm{Ti}$ implants with extracellular matrix $(\mathrm{ECM})$ proteins that are recognized by cell adhesion receptors, such as integrins [1]. In particular, fibronectin has been demonstrated to induce optimal cell responses and to effectively support cell growth when coated on titanium [2]. Cellular interaction with fibronectin is mainly mediated through the integrin-binding RGD sequence, also present in many other ECM proteins [3]. Unfortunately, native ECM proteins coated on Ti exhibit low stability and other disadvantages are the low cost-effectiveness and high immunogenicity, which generally hamper the biomedical application [4]. An alternative to overcome these drawbacks is the use of recombinant protein fragments containing functional domains characteristics from the given ECM protein. For instance, the cell attachment site (CAS) domain of fibronectin which is located at the type $\mathrm{III}_{8-10}$ segment of the molecule and contains the aforementioned RGD sequence along with the synergy sequence PHSRN, has demonstrated enhanced bone cell adhesion, proliferation and differentiation [5-8].

On another hand, there are growing evidences showing that the biomimetic functionalization of surfaces should also include spatial cues, mimicking the geometric organization of ECM [9]. When ECM proteins polymerize they generate a complex fibrillar structure which is recognized by cells mechanotransduction machinery $[10,11]$. In this regard, coating of surfaces with polymeric nanofibers (NFs) represents an emerging strategy that mimics the complex ECM structure [12,13]. There are currently three techniques available for the synthesis of NFs: electrospinning, phase separation and self-assembly [14]. There are few studies that explored the application of NFs generated by self-assembly and phase separation as scaffolds for tissue engineering $[15,16]$. In 
contrast, the use of electrospinning technology for producing NFs has received much attention in tissue engineering. Electrospinning represents an attractive technique for the processing of polymeric biomaterials into NFs because it offers the opportunity for control over thickness, dimensionality, composition and orientation of the NFs using a relatively straightforward experimental setup. In addition, porosity of the developed meshes can also be controlled, allowing to better mimic the ECM organization (recently reviewed by Liu [10]). However, there are only sparse studies reporting on the use of synthetic NFs for functionalization of Ti implants [17].

Since proteins are difficult to electrospun and generate instable often highly degradable NFs [18], in most cases NFs are generated using synthetic polymers with low rate of degradation such as polylactic acid (PLA) [19], poly(e-caprolactone) (PCL) [20] or copolyesters [21], which exhibit also good mechanical properties. A general limitation of synthetic NFs however is the lack of cell-adhesive moieties. Several studies have been concentrated on the improvement of their biological properties by coating with proteins or peptides. For instance, fibronectin and fibronectin fragments coated NFs have been demonstrated to enhance cellular interaction [22-24]. Nonetheless, the activity of most of the cell-adhesive moieties, either adsorbed or chemically grafted on the surface of NFs, though supporting the initial cell adhesion, may be of concern due to the fast degradation of NFs [24]. Such degradation can diminish the number of exposed bioactive sequences, thereby reducing the capacity of NFs for further cell colonization. In this regard, production of hybrid NFs by co-electrospinning of polymer and cell adhesive peptides may overcome this hindrance since cell-adhesive moieties could continuously drift to the polymer surface despite degradation. In addition, generation of hybrid NFs by electrospinning is advantageous compared to nanotexturing of surfaces, since it allows to produce structures with both biomechanical and biochemical stimuli without additional 
biofunctionalization steps. There are a number of studies reporting for co-electrospinning of polymers and proteins, most of which using fibrillar proteins [25-27]. Previously, we also developed a novel type of fibrinogen/PLA hybrid NFs with improved mechanical properties versus the pure fibrinogen ones, which retained the good cell-recognition characteristics of the native fibrinogen [28,29]. One step beyond is the co-electrospinning of polymers with recombinant proteins, which cannot form fibers by itself, but now offering unlimited potential to generate nanofibrous scaffolds that provide both mechanical support and instructive cues to the cells.

The present work aims to modify the Ti surface by coating with an ECM-like structure composed of PLA and fibronectin type III $_{8-10}$ recombinant fragment for enhancing osteoblasts interaction and biological response. Both components were coelectrospun to generate hybrid NFs that were further covalently attached to the Ti surface. The CAS fragment of fibronectin was added in the NFs to overcome the lack of cell adhesive capacity of PLA in order to improve cellular response. The biological response of these hybrid NFs was evaluated in terms of cell adhesion and overall cell morphology, proliferation and osteogenic differentiation of human osteoblast-like SaOS-2 cells. Pure PLA NFs and bare Ti were used as controls.

\section{Materials \& methods}

\section{Sample preparation}

Commercially pure Ti grade II (Technalloy, Spain) discs of $10 \mathrm{~mm}$ diameter and $2 \mathrm{~mm}$ height were smoothed with wet grinding paper $(800,1200$ and 2400) and then polished with a water suspension of $1 \mu \mathrm{m}$ and $0.5 \mu \mathrm{m}$ alumina particles. Mirror-like surfaces were 
rinsed in cyclohexane, isopropanol, distilled water, ethanol and acetone in an ultrasound bath and finally stored dried.

\section{Sample silanization}

Prior to silanization, samples were activated by 5 min argon plasma treatment at $100 \mathrm{~W}$ in a Standard Plasma System (FEMTO, Germany). Silanization was performed by immersing samples in 2\% (v/v) APTES (Sigma-Aldrich, USA) in anhydrous toluene at $70^{\circ} \mathrm{C}$ for $1 \mathrm{~h}$ under agitation and nitrogen atmosphere. Then samples were sonicated for 5 min in toluene followed by rinsing with toluene, acetone, isopropanol, distilled water, ethanol and acetone. Samples were incubated at $120^{\circ} \mathrm{C}$ for 5 min to increase the stable interaction of silanes with the surface. Afterwards, samples were immersed in a $7.5 \mathrm{mM}$ solution of $N$-succinimidyl-3-malimidopropionate (SMP) crosslinking agent in $N, N$ dimethylformamide (DMF) for $1 \mathrm{~h}$ under agitation at RT. Cross-linked samples were rinsed in DMF, acetone, distilled water, ethanol, acetone and nitrogen dried.

\section{Synthesis of fibronectin recombinant protein}

Human fibronectin fragment CAS, spanning the 8-10th type III repeat, was produced by standard recombinant DNA techniques as previously described [6]. Briefly, cDNA obtained from SaOS-2 cells was inserted into a pGEX-6P-1 plasmid (GE Healthcare, UK) and amplified in DH5 $\alpha$ cells (Invitrogen, USA). Constructs were then isolated, purified and sequenced. BL21 cells (New England BioLabs, UK) were transformed with the correct insert and the resulting colonies were dynamically cultured in LB broth at $37^{\circ} \mathrm{C}$ with $100 \mu \mathrm{g} / \mathrm{ml}$. Protein production was induced by adding $1 \mathrm{mM}$ isopropyl $\beta$-D-1thiogalactopyranoside (IPTG) during 4h. Bacterial suspensions were centrifuged, resuspended and sonicated. Lysed bacteria were centrifuged and the CAS fragment was purified from the resulting supernatant using a GSTrap affinity column (GE Healthcare). 
GST-tag was removed on-column and the purified CAS fragment was resolved by electrophoresis. The protein concentration was quantified by BCA method.

\section{Electrospinning}

Both CAS recombinant fragment and poly(L-lactide-co-D,L-lactide) (PLA) were dissolved in 1-1-1,3-3-3-hexafluoroisopropanol (HFIP) and mixed at final concentrations of $100 \mu \mathrm{g} / \mathrm{ml}$ and $4 \%$, respectively. The obtained solution was loaded in a conventional $10 \mathrm{ml}$ syringe and extruded through a trimmed needle using a syringe pump (Aitecs, Lithuania). NFs were randomly deposited onto silanized Ti discs by electrospinning the solution for 2 min under electric field generated by a high voltage supply (Glassman High Voltage Inc., USA). The applied voltage was $30 \mathrm{kV}$, the distance between the needle tip and the collector was $125 \mathrm{~mm}$ and the pump flow rate was $0.5 \mathrm{ml} / \mathrm{h}$. NFs of PLA without CAS fragment were used as separate samples. NFs of both PLA and CAS/PLA were also deposited onto plain $\mathrm{Ti}$ and plasma activated $\mathrm{Ti}$ for the dettachment test.

\section{Nanofibers characterization}

\section{Morphology}

The electrospun PLA and CAS/PLA NFs were morphologically characterized by scanning electron microscopy (SEM, Jeol JSM-7001F, Japan). SEM images were acquired at an accelerating voltage of $5 \mathrm{kV}$. Nanofiber diameters were calculated using the SmartTiff software (Carl Zeiss, Germany).

\section{Roughness characterization}

Surface roughness was evaluated using a white light interferometer microscope (Wyko NT9300 Optical Profiler, Veeco Instruments, USA) in vertical scanning interferometry mode. Four different samples for each condition were measured at three different 
positions. Data filtering and analysis were performed with Wyko Vision 4.10 software (Veeco Instruments). A Fourier filter with cut-off between 5 and $1500 \mathrm{~nm}$ was used to remove waviness of nanofibers. The average roughness $(\mathrm{Ra})$, which is the arithmetic average of the absolute values of the surface departures from the mean plane, was characterized.

\section{CAS integration within fibers}

The presence of CAS fragment in CAS/PLA NFs was confirmed by staining of CAS with Atto 550 NHS ester (Sigma-Aldrich) fluorescence probe before electrospinning the mixture. Briefly, the CAS fragment was incubated with $10 \mu \mathrm{g}$ of Atto 550 NHS ester in 0.1 M bicarbonate buffer for $2 \mathrm{~h}$ at $\mathrm{RT}$ in dark. Then, the labeled protein was separated from unreacted dye by gel permeation chromatography using a Sephadex G-25 column (Sigma-Aldrich). The column was previously equilibrated with phosphate-buffered saline (PBS) at a flow rate of $3.64 \mathrm{ml} / \mathrm{min}$ using a peristaltic pump. The labeled CAS was loaded at a flow rate of $2 \mathrm{ml} / \mathrm{min}$ and eluted with PBS. Fractions were quantified spectrophotometrically at $280 \mathrm{~nm}$ and confirmed by BSA method while the fluorescence was measured using a fluorescent photometer FluoroMax-4, Horiba-Jobin Yvon set at $520 \mathrm{~nm}$ excitation and $542 \mathrm{~nm}$ emission. Labeled CAS was mixed with PLA and electrospun as above. The fluorescent CAS in the CAS/PLA NFs was observed morphologically and photographed using an Axio Observer Z1 fluorescence microscope (Carl Zeiss). PLA NFs without CAS fragment were used as negative control.

\section{Superficial availability of CAS fragment}

The presence of available CAS on the surface of CAS/PLA NFs was evaluated by immunostaining. For that purpose the electrospun NFs were fixed with $4 \%$ paraformaldehyde (PFA) for $20 \mathrm{~min}$ and rinsed three times in buffer (20 mM glycine in 
PBS). Samples were further blocked with $1 \%$ bovine serum albumin (BSA) for 15 min and incubated with rabbit anti-human fibronectin antibody (1:300; Sigma-Aldrich) in 1\% BSA for $1 \mathrm{~h}$, followed by three more washes as above. Then, samples were incubated with Alexa Fluor® 488 goat anti-mouse antibody (1:1000) (Invitrogen) for $1 \mathrm{~h}$ and rinsed twice before mounted in Mowiol. Images were acquired using an E600 fluorescence microscope (Nikon, Japan) and processed with Cell F software (Olympus, Japan).

\section{Solvent stability and detachment from supports}

The release of CAS fragment from hybrid CAS/PLA NFs over time was evaluated by measuring the fluorescent signal from Atto-abelled CAS in the medium. For this purpose, Atto labeled fluorescent CAS was electrospun together with PLA and resulting NFs incubated in McCoy's 5A medium (Sigma-Aldrich) at $37^{\circ} \mathrm{C}$ and $5 \% \mathrm{CO}_{2}$ in a humidified atmosphere. The media were collected at day 1, 3 and 7 and the released fluorescence was quantified as described above at $494 \mathrm{~nm}$ excitation and $525 \mathrm{~nm}$ emission correcting for the auto fluorescence of the medium.

To verify the attachment stability of NFs to supports, triplicate samples were immersed in $5 \mathrm{ml}$ PBS and placed in an ultrasound bath for $20 \mathrm{~min}$. The detachment of NFs was evaluated visually and the time of detachment was considered when NFs were completely detached from the support. In the case they were still attached after $20 \mathrm{~min}$ sonication (>20 min) the fibers were accepted as stably attached.

\section{Biological characterization}

\section{Cell culture}

Human osteoblast-like SaOS-2 cells (ATCC, USA) were used as in vitro model for studying the bioactivity of NFs due to their homogeneity and their osteoblastic expression 
profile [30]. SaOS-2 cells were cultured in McCoy's 5A medium (Sigma-Aldrich) supplemented with $10 \%$ fetal bovine serum (FBS), penicillin (50 U/ml), streptomycin (50 $\mu \mathrm{g} / \mathrm{ml})$, sodium pyruvate $(1 \mathrm{mM})$, L-glutamine $(2 \mathrm{mM})$ and HEPES $(20 \mathrm{mM})$ (all from Invitrogen) at $37^{\circ} \mathrm{C}$ and $5 \% \mathrm{CO}_{2}$ in a humidified atmosphere. Medium was changed every two days and about confluent cells were harvested for the experiments using TrypLE reagent (Invitrogen).

\section{Cell adhesion}

Cells $\left(40 \times 10^{3}\right)$ suspended in serum-free medium were seeded onto each sample and allowed to adhere for $4 \mathrm{~h}$. Then, samples were washed with PBS and the attached cells were lysed with $300 \mu \mathrm{l}$ of M-PER (Mammalian Protein Extraction Reagent; Thermo Scientific, USA). The relative number of attached cells was quantified by measuring the lactate dehydrogenase ( $\mathrm{LDH})$ activity using the Cytotoxicity Detection $\mathrm{Kit}^{\mathrm{PLUS}} \mathrm{LDH}$ (Roche Applied Science, Germany). The samples were measured spectrophotometrically at $492 \mathrm{~nm}$ using a PowerWave HT microplate reader (Bio-Tek Instruments, USA) and the number of cells was calculated using a calibration curve prepared with known cell numbers.

\section{Cell spreading assay}

The cells, fixed as above, were washed three times with PBS, permeabilized with $0.1 \%$ Triton X-100 (Sigma-Aldrich) for 5 min, blocked with 1\% BSA in PBS for 30 min and incubated in Alexa Fluor® 546 Phalloidin (1:300; Invitrogen) for 30 min to view the actin cytoskeleton. Samples were further washed and mounted in Mowiol 488 to be visualized and photographed on fluorescent microscope as above. The area of cells spreading was calculated from at least five randomly acquired images using the corresponding ImageJ software (NIH, USA). 


\section{Cell proliferation}

Cell proliferation was measured by LDH assay as above. SaOS-2 cells were seeded at $4 \times 10^{4}$ cells per sample in serum free medium. After $4 \mathrm{~h}, 10 \%$ serum was added and the medium exchanged each two days. At days 3, 7, 14 and 21 the samples were washed with PBS and lysed with $300 \mu \mathrm{l}$ of M-PER. The number of cells at each time point was calculated by measuring the LDH as explained above.

\section{Cell differentiation}

The osteoblastic cell differentiation was assessed by measuring the alkaline phosphatase (ALP) activity. The ALP was quantified from the same extract collected for cell proliferation using the SensoLyte ${ }^{\circledR}$ pNPP Alkaline Phosphatase Assay Kit (AnaSpec, USA) following the manufacturer's instructions. At each time point (3, 7, 14 and 21 days) the ALP activity was measured spectrophotometrically at $405 \mathrm{~nm}$ using a PowerWave HT microplate reader (Bio-Tek) and normalized to the corresponding number of cells obtained for the same time points.

\section{Statistical analysis}

All experiments were performed in triplicates. The data are presented as mean \pm SEM (standard error of the mean). A non-parametric Kruskal-Wallis test followed by MannWhitney test with Bonferroni correction was used to determine statistically significant differences with $\mathrm{p}<0.05$.

\section{Results}


Electrospun PLA and CAS/PLA NFs were randomly deposited over the polished Ti surface (Figs. 1A and 1B) resulting in a homogenous NFs layer. Pure PLA NFs showed an average diameter of $220 \pm 4 \mathrm{~nm}$ (Fig. 1C). In contrast, CAS/PLA NF presented a bimodal distribution, with an average diameter of thicker fibers $361 \pm 16 \mathrm{~nm}$ and of thin fibers $95 \pm 10 \mathrm{~nm}$.

Similar higher values for the surface roughness were observed for PLA and CAS/PLA NFs, which were approximately $1000 \mathrm{~nm}$ (Fig. 2), compared to plain Ti.

The integration of CAS inside the PLA NFs was monitored observing the fluorescence of Atto-conjugated CAS containing samples. No fluorescence was found from plane PLA NFs (Fig. 2A) while CAS/PLA NFs were intensively stained (Fig. 2B) confirming the incorporation of fragment. The presence of CAS at the surface of PLA NFs was further monitored by immunostaining. Fluorescence signal was only observed in CAS/PLA NFs (Fig. 2D) and again no signal of nonspecific fluorescence was detected from pure PLA NFs (Fig. 2C).

The stability of CAS incorporation in CAS/PLA NFs upon incubation in cell culture medium was estimated by measuring the release of Atto 550-labeled CAS during different time periods (Fig. 3). High release of CAS was observed at day 1, followed by sustained increase of the fluorescence signal at days 3 and 7 of incubation.

The attachment stability of NFs on the Ti surface was evaluated by sonication (Table 1). In the case of pure PLA NFs the stability increased after plasma and plasma plus silanization (APTES) treatments. In the latter case they remained completely attached to the surface even after 20 min of sonication. Interestingly the presence of CAS in PLA NFs increased their stability even without any treatment.

\section{Cell adhesion}


The number of cells adhered to PLA and CAS/PLA NFs after 4h of incubation was similar, showing no statistically significant differences when compared to Ti without NFs (Fig. 4A). However, the cell spreading area increased significantly, approximately two times on pure PLA NFs and 2.5 times in the presence of CAS compared to the bare Ti surface (Fig. 4B). In general, the cells cultured on Ti surface showed a rather rounded morphology with less developed actin cytoskeleton (Fig. 4C), visible on the high magnification images (Fig. 4F). On PLA NFs the cells spread better, some of them developing well organized actin stress fibers (Figs. 4D and 4G). In the presence of CAS however almost all cells presented a flattened morphology with well-developed actin cytoskeleton (Figs. 4E and 4H).

\section{Cell proliferation}

The number of cells increased gradually with the time of culture at all surfaces (Fig. 5A) but with a clear tendency for better cell growth on the samples containing NFs, showing statistically significant differences already after 3 days compared to bare Ti. The number of cells however was significantly higher on CAS/PLA NFs, compared to all other samples at days 14 and 21.

\section{Cell differentiation}

The differentiation of pre-osteoblastic SaOS-2 cells into the osteoblastic phenotype was evaluated by measuring the ALP activity. ALP levels increased with time in all substrates, but no significant differences between them was found at 3,7 and 14 days of culture (Fig. 5B). There was however a statistically significant increase in the ALP activity at day 21 on both NFs-coated surfaces compared to bare Ti but markedly higher when the NFs contained the CAS fragment. ALP activity was approximately 1.5 times higher on pure PLA NFs and 2.5 times more on CAS/PLA NFs compared to bare Ti. 


\section{Discussion}

This paper describes an innovative strategy to overcome the lack of bioactivity of $\mathrm{Ti}$ implants through creating an ECM-like microenvironment on their surface that mimics to some extent the natural spatiotemporal cues of the bone connective tissue. In this respect the use of electrospun NFs provide many advantages due to the structural similarity with ECM fibers [10]. NFs itself provide organizational cues that are recognized by the cells as ECM specific stimuli. On the other hand however the successful cellular interaction require the same level of stiffness between cells and surrounding matrix [31,32], which is obviously not the case with metal implants. The nanofibers coating however, to our view overcome this obstacle.

Metals are commonly used as collector for electrospun fibers, and therefore it is relatively straight forward to use NFs for coating metal implants, and it is the case also for Ti. It was previously shown for example that the deposition of PCL NFs on Ti surface improve significantly the interaction with cells [20]. Likewise our results demonstrate that SaOS-2 cells spread better on PLA NFs coated compared to bare Ti surface, which suggests that the fibrilar environment itself enhances cell adhesion, apart from the specific effect of CAS functionalization. Similar cell behaviour was already observed in our previous study utilising fibrinogen based NFs [18,29] where a significant increase in the attachment and spreading area of endothelial cells was found when compared to flat fibrinogen-coated surface. The mechanism of this effect of NFs is not entirely clear though it is generally accepted that the geometry of substratum is a key parameter for the successful cellular interaction and has to be considered when engineer biomimetic surfaces $[11,33,34]$. Indeed, distinct organizational features are strongly influential in 
directing cell behaviour and functionality [34,35], and within them the NFs receive a considerable attention [10].

An important issue is the successful adhesion of NFs to the implant surface avoiding their peeling off in vivo. Herein, we proposed to chemically bond the NFs to the Ti surface, a methodology commonly used for attaching soluble biomolecules $[6,36]$. The use of SMP as crosslinking reagent generates carboxyl groups which interact with the PLA side chains thus producing a covalent bonding. Indeed we show that the silanization of Ti samples substantially increased the binding stability of PLA NFs compared to plasma-activated and bare Ti samples (Table 1). The presence of CAS within the hybrid NFs also increased their binding to the Ti surface, even without any surface treatment, probably due to the better adsorption of the peptide content. It is important to highlight however that only attachment strength of NFs on Ti surface has been evaluated and further experiments should be performed to ensure mechanical stability of NFs in in vivo situations. It has to be mentioned also that a portion of thinner nanofibers were obtained when PLA was co-electrospun with CAS fragment leading to a bimodal size distribution. Presumably it is connected with the heterogeneity of the polymer mixture [37], but it is worthy to mention that thinner fibers attach better to the surfaces.

The main advantage of co-electrospinning of a polymer with non-crosslinked peptide is that during the degradation of the polymer, new peptide molecules will appear at the polymer surface assuring sustained bioactivity. This was demonstrated in the present study by the continuous release of fluorescently labelled CAS fragment to the medium also by the sustained bioactivity [38] obviously preserved during the electrospinning process [39]. 
Apart from the beneficial effect of NFs itself, confirming our previous and also other studies $[10,18,29,34]$, a particularly important and novel observation is that CAS fragment further improve the cellular interaction and functionality of SaOS-2 cells. CAS functionalization did not affect cell attachment but increased significantly cell spreading. This effect should be attributed to the presence of RGD and PHSRN motifs in an appropriate three dimensional conformation. The RGD sequence is recognized by several integrins [40], therefore, this peptide has been widely used for functionalization of biomaterials, including PLA [41]. However, although RGD induces cell adhesion its involvement in cell spreading is still on controversy. Several studies point out the requirement of additional sequences for promoting focal adhesion complexes formation and cell spreading initiation. Indeed, combination of RGD with other synergistic sequences, such as PHSRN of fibronectin, have demonstrated to improve initial cellular interaction and spreading [42]. Nonetheless, presentation of both RGD and PHSRN sequences at appropriate configuration is crucial to maintain their synergic activity $[36,43,44]$, which is obviously the case in our CAS fragment. Indeed, our previous studies and also other authors demonstrated a clear cell spreading potency of this recombinant fragment on mesenchymal stem cells $[5,6,45]$ and osteoblasts $[46,47]$. The interaction of cells with CAS fragment goes via the integrin receptors, mainly $\alpha 5 \beta 1$, which induces the formation of focal adhesion complexes and FAK phosphorylation [48]. The later is responsible for the activation of distinct signalling cascades that regulate actin polymerization and cytoskeleton reorganization resulting in cell spreading, an event crucial for the regulation of cell survival, proliferation and differentiation [49].

In addition, CAS fragment has also been demonstrated to induce cell proliferation at similar levels to that of full-length fibronectin [6,50]. This effect, observed also in this study, is presumably due to the activation of $\alpha 5 \beta 1$ integrin signalling cascade, which is 
shown to be important for maintaining the osteoblast cell cycle [51,52]. Although the optimal cellular responses require the presence of the HBII recombinant domain [6], which acts in synergy with CAS due to the growth factor binding capacity [53], in the present study we observed another synergistic effect, between the nanofibrous environment and the CAS fragment, without the necessity of the HBII contribution. The presence of additional nano-dimensional features obviously enhances independently cell adhesion (as discussed above) and proliferation [54]. It is important to mention that the time of exposure of the electrospinning jet was set on 2 min, giving a homogenous NFs mat of approximately $10 \mu \mathrm{m}$ and a pore size of about $10 \mu \mathrm{m}$ (data not shown) that ensures direct cellular contact to the NFs avoiding contact with the Ti surface. It is difficult to ascertain if the increased cell adhesion on PLA NFs is attributed to the increased roughness compared to Ti surfaces, to the 3-dimensional architecture of NFs or to both parameters. It has to be mentioned here that enhanced cell activity on CAS/PLA NFs compared to PLA NFs should be attributed to the presence of CAS on the nanofibers and not to additional topographical features of NFs. In fact, no significant differences in roughness were observed between both PLA and CAS/PLA NFs.

This synergistic effect of CAS and the nanofibers environment could also explain the increased differentiation potential of osteoblastic cells on CAS/PLA NFs. Osteoblast differentiation can be induced by several routes and one of them includes the topographical modifications $[55,56]$ though distinct chemical stimuli also play role. For instance, the CAS fragment has been described to induce cell differentiation at similar levels to native fibronectin [52]. Cell differentiation requires activation of different pathways that converge into increased expression of RUNX2-regulated genes $[57,58]$, which in turn regulate the ALP activity. The present study demonstrates a significant 
increase in ALP activity in CAS containing NFs versus pure PLA NFs, but both overriding the bare Ti surface, thus confirming the existence of a synergistic effect.

\section{Conclusion}

Collectively, this study shows that the co-electrospinning of polymer and recombinant protein molecules is a promising strategy to combine biomechanical and bioactive signals, thereby generating ECM-like stimuli on Ti surfaces. In particular, the coating of Ti with hybrid NFs containing the recombinant fibronectin fragment CAS significantly improved the biological response of osteoblast-like SaOS-2 cells apart from the intrinsically incentive effect of PLA NFs itself. A significant increase of cell spreading combined with enhanced cell proliferation and differentiation were observed on plane PLA NFs further augmented on CAS/PLA NFs suggesting a synergistic effect. These observations suggest that coating of Ti implants with electrospun NFs, and particularly with hybrid CAS/PLA NFs may improve significantly their osseointegration potential. To the best of our knowledge, this is the first work that shows hybrid NFs containing a recombinant protein, which offers virtually unlimited potential for the future use of NFs in regenerative medicine.

\section{Financial \& competing interests disclosure}

This work was supported by CIBER-BBN Spain (project BIOSURFACES) and the European Commission through the FP7 Industry-Academia Partnerships and Pathways (IAPP) project FIBROGELNET. The authors acknowledge also the financial support provided by the Spanish Government through Projects MAT2015-67183-R and MAT 2015-69315-C3 (MINECO/FEDER, UE). JGM acknowledges his personal support through PDJ2014 fellowship from the Agency for Management of University and 
Research Grants (AGAUR) of the Catalan Government. MPG acknowledges financial support from the Generalitat de Catalunya through the ICREA Academia Award.

\section{Summary points}

- Electrospun hybrid nanofibers composed of PLA and a recombinant fragment from fibronectin were fabricated.

- Hybrid nanofibers covalently attached at the titanium surface mimic the natural extracellular matrix.

- Continuous release of the recombinant fragment from the nanofibers ensures sustained bioactivity during polymer degradation.

- Activity of the recombinant fragment co-electrospun with PLA was preserved during electrospinning process improving cell interaction.

- Activity of the recombinant fragment co-electrospun with PLA was preserved during electrospinning process improving cell interaction.

- Hybrid CAS/PLA nanofibers produced biochemical and biomechanical synergistic effects on cells increasing cell spreading, cell proliferation and cell differentiation compared to pure PLA nanofibers.

- Coating of titanium implants with hybrid nanofibers composed of a fibronectin recombinant fragment and PLA may improve their osseointegration potential.

\section{References}


1. Ruoslahti E. RGD and Other Recognition Sequences for Integrins. Annu. Rev. Cell Dev. Biol. [Internet]. 12(1), 697-715 (1996). Available from: http://www.annualreviews.org/doi/abs/10.1146/annurev.cellbio.12.1.697.

2. Rapuano BE, Hackshaw KM, Schniepp HC, MacDonald DE. Effects of coating a titanium alloy with fibronectin on the expression of osteoblast gene markers in the MC3T3 osteoprogenitor cell line. Int. J. Oral Maxillofac. Implants. 27(5), 1081-1090 (2012).

3. Arnaout MA, Mahalingam B, Xiong J-P. INTEGRIN STRUCTURE, ALLOSTERY, AND BIDIRECTIONAL SIGNALING. Annu. Rev. Cell Dev. Biol. [Internet]. 21(1), 381-410 (2005). Available from: http://www.ncbi.nlm.nih.gov/pubmed/16212500.

4. Shekaran A, García AJ. Extracellular matrix-mimetic adhesive biomaterials for bone repair. J. Biomed. Mater. Res. - Part A. 96 A(1), 261-272 (2011).

5. Herranz-Diez C, Li Q, Lamprecht C, et al. Bioactive compounds immobilized on Ti and TiNbHf: AFM-based investigations of biofunctionalization efficiency and cell adhesion. Colloids Surfaces B Biointerfaces [Internet]. 136, 704-711 (2015). Available from: http://linkinghub.elsevier.com/retrieve/pii/S0927776515302393.

6. Herranz-Diez C, Mas-Moruno C, Neubauer S, et al. Tuning Mesenchymal Stem Cell Response onto Titanium-Niobium-Hafnium Alloy by Recombinant Fibronectin Fragments. ACS Appl. Mater. Interfaces. 8(4), 2517-2525 (2016).

7. Petrie TA, Reyes CD, Burns KL, García AJ. Simple application of fibronectinmimetic coating enhances osseointegration of titanium implants. J. Cell. Mol. Med. 13(8 B), 2602-2612 (2009). 
8. Petrie TA, Raynor JE, Dumbauld DW, et al. Multivalent integrin-specific ligands enhance tissue healing and biomaterial integration. Sci. Transl. Med. [Internet]. 2(45), 45ra60 (2010). Available from:

http://www.pubmedcentral.nih.gov/articlerender.fcgi?artid=3128787\&tool=pmce ntrez\&rendertype $=$ abstract.

9. Santos E, Orive G, M R, Luis J. Cell-Biomaterial Interaction: Strategies To Mimic The Extracellular Matrix [Internet]. In: On Biomimetics. InTech, 529-558 (2011). Available from: http://cdn.intechopen.com/pdfs/18181/InTechCell_biomaterial_interaction_strategies_to_mimic_the_extracellular_matrix.pdf.

10. Liu H, Ding X, Zhou G, Li P, Wei X, Fan Y. Electrospinning of Nanofibers for Tissue Engineering Applications. J. Nanomater. [Internet]. 2013, 1-11 (2013). Available from: http://www.hindawi.com/journals/jnm/2013/495708/.

11. Dvir T, Timko BP, Kohane DS, Langer R. Nanotechnological strategies for engineering complex tissues. Nat. Nanotechnol. [Internet]. 6(1), 13-22 (2011). Available from: http://www.ncbi.nlm.nih.gov/pubmed/21151110.

12. Sill TJ, von Recum HA. Electrospinning: Applications in drug delivery and tissue engineering. Biomaterials. 29(13), 1989-2006 (2008).

13. Pham QP, Sharma U, Mikos AG. Electrospinning of polymeric nanofibers for tissue engineering applications: a review. Tissue Eng. [Internet]. 12(5), 1197-211 (2006). Available from: http://www.ncbi.nlm.nih.gov/pubmed/16771634.

14. Vasita R, Katti DS. Nanofibers and their applications in tissue engineering. Int. J. Nanomedicine. 1(1), 15-30 (2006).

15. Hartgerink JD, Beniash E, Stupp SI. Peptide-amphiphile nanofibers: A versatile 
scaffold for the preparation of self-assembling materials. Proc. Natl. Acad. Sci. [Internet]. 99(8), 5133-5138 (2002). Available from: http://www.pnas.org/cgi/doi/10.1073/pnas.072699999.

16. Woo KM, Chen VJ, Ma PX. Nano-fibrous scaffolding architecture selectively enhances protein adsorption contributing to cell attachment. J. Biomed. Mater. Res. [Internet]. 67A(2), 531-537 (2003). Available from: http://doi.wiley.com/10.1002/jbm.a.10098.

17. Ravichandran $\mathrm{R}, \mathrm{Ng} \mathrm{CC}$, Liao S, et al. Biomimetic surface modification of titanium surfaces for early cell capture by advanced electrospinning. Biomed. Mater. 7(1), 15001 (2011).

18. Gugutkov D, Gustavsson J, Ginebra MP, Altankov G. Fibrinogen nanofibers for guiding endothelial cell behavior. Biomater. Sci. [Internet]. 1(10), 1065 (2013). Available from: http://xlink.rsc.org/?DOI=c3bm60124b.

19. Zeng J, Chen X, Xu X, et al. Ultrafine fibers electrospun from biodegradable polymers. J. Appl. Polym. Sci. 89(4), 1085-1092 (2003).

20. Lee SJ, Oh SH, Liu J, Soker S, Atala A, Yoo JJ. The use of thermal treatments to enhance the mechanical properties of electrospun poly(e-caprolactone) scaffolds. Biomaterials. 29(10), 1422-1430 (2008).

21. Keun Kwon I, Kidoaki S, Matsuda T. Electrospun nano- to microfiber fabrics made of biodegradable copolyesters: Structural characteristics, mechanical properties and cell adhesion potential. Biomaterials. 26(18), 3929-3939 (2005).

22. Mukhatyar VJ, Salmerón-Sánchez M, Rudra S, et al. Role of fibronectin in topographical guidance of neurite extension on electrospun fibers. Biomaterials. 
32(16), 3958-3968 (2011).

23. Kim J-E, Noh K-T, Yu H-S, Lee H-Y, Jang J-H, Kim H-W. A Fibronectin Peptide-Coupled Biopolymer Nanofibrous Matrix to Speed Up Initial Cellular Events. Adv. Eng. Mater. [Internet]. 12(4), B94-B100 (2010). Available from: http://doi.wiley.com/10.1002/adem.200980008.

24. Regis S, Youssefian S, Jassal M, Phaneuf MD, Rahbar N, Bhowmick S.

Fibronectin adsorption on functionalized electrospun polycaprolactone scaffolds: Experimental and molecular dynamics studies. J. Biomed. Mater. Res. - Part A. 102(6), 1697-1706 (2014).

25. Zhang Y, Ouyang H, Chwee TL, Ramakrishna S, Huang ZM. Electrospinning of gelatin fibers and gelatin/PCL composite fibrous scaffolds. J. Biomed. Mater. Res. - Part B Appl. Biomater. 72(1), 156-165 (2005).

26. Khadka DB, Haynie DT. Protein- and peptide-based electrospun nanofibers in medical biomaterials. Nanomedicine Nanotechnology, Biol. Med. 8(8), 12421262 (2012).

27. Yin A, Zhang K, McClure MJ, et al. Electrospinning collagen/chitosan/poly( $<\mathrm{scp}>\mathrm{L}</ \mathrm{scp}>$-lactic acid- $c o-\epsilon$-caprolactone) to form a vascular graft: Mechanical and biological characterization. J. Biomed. Mater. Res. Part A [Internet]. 101A(5), 1292-1301 (2013). Available from: http://www.ncbi.nlm.nih.gov/pubmed/23065755.

28. Pereira M, Rybarczyk BJ, Odrljin TM, Hocking DC, Sottile J, Simpson-Haidaris PJ. The incorporation of fibrinogen into extracellular matrix is dependent on active assembly of a fibronectin matrix. J. Cell Sci. 115(Pt 3), 609-617 (2002). 
29. Gugutkov D, Gustavsson J, Cantini M, Salmeron-Sánchez M, Altankov G.

Electrospun fibrinogen-PLA nanofibres for vascular tissue engineering. J. Tissue Eng. Regen. Med. [Internet]. 4(7), In press (2016). Available from:

http://doi.wiley.com/10.1002/term.2172.

30. Czekanska, E. M.; Stoddart, M. J.; Richards, R. G. \& Hayes JS. In search of an osteoblast cell model for in vitro research. Eur. Cells Mater. 24, 1-17 (2012).

31. Grinnell F. Focal adhesion sites and the removal of substratum-bound fibronectin. J. Cell Biol. 103(6 II), 2697-2706 (1986).

32. Hubbell JA. Materials as morphogenetic guides in tissue engineering. Curr. Opin. Biotechnol. 14(5), 551-558 (2003).

33. Théry M, Pépin A, Dressaire E, Chen Y, Bornens M. Cell distribution of stress fibres in response to the geometry of the adhesive environment. Cell Motil. Cytoskeleton. 63(6), 341-355 (2006).

34. Wade RJ, Burdick JA. Engineering ECM signals into biomaterials. Mater. Today. 15(10), 454-459 (2012).

35. Daley WP, Peters SB, Larsen M. Extracellular matrix dynamics in development and regenerative medicine. J. Cell Sci. [Internet]. 121(Pt 3), 255-64 (2008). Available from: http://www.ncbi.nlm.nih.gov/pubmed/18216330.

36. Fraioli R, Dashnyam K, Kim J-H, et al. Surface guidance of stem cell behavior: Chemically tailored co-presentation of integrin-binding peptides stimulates osteogenic differentiation in vitro and bone formation in vivo. Acta Biomater. [Internet]. 43, 269-281 (2016). Available from: http://linkinghub.elsevier.com/retrieve/pii/S1742706116303841. 
37. Deitzel J., Kleinmeyer J, Harris D, Beck Tan N. The effect of processing variables on the morphology of electrospun nanofibers and textiles. Polymer (Guildf). [Internet]. 42(1), 261-272 (2001). Available from:

http://linkinghub.elsevier.com/retrieve/pii/S0032386100002500.

38. Matsuzaka K, Walboomers F, Ruijter A, Jansen J a. Effect of microgrooved poly1-lactic (PLA) surfaces on proliferation, cytoskeletal organization, and mineralized matrix formation of rat bone marrow cells. Clin. Oral Implants Res. [Internet]. 11(4), 325-333 (2000). Available from: http://doi.wiley.com/10.1034/j.1600-0501.2000.011004325.x.

39. Chew SY, Wen J, Yim EKF, Leong KW. Sustained release of proteins from electrospun biodegradable fibers. Biomacromolecules. 6(4), 2017-2024 (2005).

40. Humphries JD, Byron A, Humphries MJ. Integrin ligands at a glance. J. Cell Sci. 119(19), 3901-3903 (2006).

41. Hu YH, Winn SR, Krajbich I, Hollinger JO. Porous polymer scaffolds surfacemodified with arginine-glycine-aspartic acid enhance bone cell attachment and differentiation in vitro. J. Biomed. Mater. Res. part A. 64A(3), 583-590 (2003).

42. Aota SI, Nomizu M, Yamada KM. The short amino acid sequence Pro-His-SerArg-Asn in human fibronectin enhances cell-adhesive function. J. Biol. Chem. 269(40), 24756-24761 (1994).

43. Benoit DSW, Anseth KS. The effect on osteoblast function of colocalized RGD and PHSRN epitopes on PEG surfaces. Biomaterials. 26(25), 5209-5220 (2005).

44. Mardilovich A, Craig JA, McCammon MQ, Garg A, Kokkoli E. Design of a novel fibronectin-mimetic peptide-amphiphile for functionalized biomaterials. 
Langmuir. 22(7), 3259-3264 (2006).

45. Agarwal R, González-García C, Torstrick B, Guldberg RE, Salmerón-Sánchez M, García AJ. Simple coating with fibronectin fragment enhances stainless steel screw osseointegration in healthy and osteoporotic rats. Biomaterials. 63, 137$145(2015)$.

46. Cutler SM, García AJ. Engineering cell adhesive surfaces that direct integrin ??5??1 binding using a recombinant fragment of fibronectin. Biomaterials. 24(10), 1759-1770 (2003).

47. $\mathrm{Ku} \mathrm{Y}$, Chung $\mathrm{CP}$, Jang JH. The effect of the surface modification of titanium using a recombinant fragment of fibronectin and vitronectin on cell behavior. Biomaterials. 26(25), 5153-5157 (2005).

48. Petrie TA, Capadona JR, Reyes CD, García AJ. Integrin specificity and enhanced cellular activities associated with surfaces presenting a recombinant fibronectin fragment compared to RGD supports. Biomaterials. 27(31), 5459-5470 (2006).

49. Wozniak M a, Modzelewska K, Kwong L, Keely PJ. Focal adhesion regulation of cell behavior. Biochim. Biophys. Acta [Internet]. 1692(2-3), 103-19 (2004). Available from: http://www.ncbi.nlm.nih.gov/pubmed/15246682.

50. Kim T Il, Jang JH, Chung CP, Ku Y. Fibronectin fragment promotes osteoblastassociated gene expression and biological activity of human osteoblast-like cell. Biotechnol. Lett. 25(23), 2007-2011 (2003).

51. Moursi AM, Globus RK, Damsky CH. Interactions between integrin receptors and fibronectin are required for calvarial osteoblast differentiation in vitro. J. Cell Sci. 110, 2187-2196 (1997). 
52. Martino MM, Mochizuki M, Rothenfluh DA, Rempel SA, Hubbell JA, Barker TH. Controlling integrin specificity and stem cell differentiation in 2D and 3D environments through regulation of fibronectin domain stability. Biomaterials [Internet]. 30(6), 1089-1097 (2009). Available from:

http://apps.webofknowledge.com/full_record.do?product=WOS\&search_mode= GeneralSearch\&qid=221\&SID=1DANiOI7PBF9a35fN5h\&page=1\&doc=6.

53. Martino MM, Hubbell JA. The 12th-14th type III repeats of fibronectin function as a highly promiscuous growth factor-binding domain. FASEB J. [Internet]. 24(12), 4711-4721 (2010). Available from:

http://eutils.ncbi.nlm.nih.gov/entrez/eutils/elink.fcgi?dbfrom=pubmed\&id=20671 107\&retmode=ref\&cmd=prlinks\%5Cnpapers3://publication/doi/10.1096/fj.09151282.

54. Lord MS, Foss M, Besenbacher F. Influence of nanoscale surface topography on protein adsorption and cellular response. Nano Today. 5(1), 66-78 (2010).

55. Dalby MJ, Gadegaard N, Tare R, et al. The control of human mesenchymal cell differentiation using nanoscale symmetry and disorder. Nat. Mater. 6(5), 407413 (2007).

56. Mendonça G, Mendonça DBS, Simões LGP, et al. The effects of implant surface nanoscale features on osteoblast-specific gene expression. Biomaterials. 30(25), 4053-4062 (2009).

57. Komori T. Regulation of bone development and maintenance by Runx2. Front. Biosci. [Internet]. 13(13), 898 (2008). Available from: http://www.bioscience.org/2008/v13/af/2730/list.htm. 
58. Komori T. Regulation of Osteoblast Differentiation by Runx2 [Internet]. In:

Advances in Experimental Medicine and Biology. , 43-49 (2009). Available

from: http://link.springer.com/10.1007/978-1-4419-1050-9_5.

1. Ruoslahti E. RGD and other recognition sequences for integrins. Annu. Rev. Cell Dev. Biol. 12(1), 697-715 (1996).

2. Rapuano BE, Hackshaw KM, Schniepp HC, MacDonald DE. Effects of coating a titanium alloy with fibronectin on the expression of osteoblast gene markers in the MC3T3 osteoprogenitor cell line. Int. J. Oral Maxillofac. Implants. 27(5), 10811090 (2012).

3. Arnaout MA, Mahalingam B, Xiong J-P. Integrin structure, allostery, and bidirectional signaling. Annu. Rev. Cell Dev. Biol. 21(1), 381-410 (2005).

4. Shekaran A, García AJ. Extracellular matrix-mimetic adhesive biomaterials for bone repair. J. Biomed. Mater. Res. - Part A. 96 A(1), 261-272 (2011).

5. Herranz-Diez C, Li Q, Lamprecht C, et al. Bioactive compounds immobilized on $\mathrm{Ti}$ and TiNbHf: AFM-based investigations of biofunctionalization efficiency and cell adhesion. Colloids Surf. B. Biointerfaces 136, 704-11 (2015).

6. Herranz-Diez C, Mas-Moruno C, Neubauer S, et al. Tuning mesenchymal stem cell response onto Titanium-Niobium-Hafnium alloy by recombinant fibronectin fragments. ACS Appl. Mater. Interfaces. 8(4), 2517-2525 (2016).

7. Petrie TA, Reyes CD, Burns KL, García AJ. Simple application of fibronectinmimetic coating enhances osseointegration of titanium implants. J. Cell. Mol. Med. 13(8 B), 2602-2612 (2009).

8. Petrie TA, Raynor JE, Dumbauld DW, et al. Multivalent integrin-specific ligands enhance tissue healing and biomaterial integration. Sci. Transl. Med. 2(45), 45ra60 (2010).

9. Santos E, Orive G, M R, Luis J. Cell-Biomaterial Interaction: Strategies To Mimic The Extracellular Matrix. In: On Biomimetics. InTech, 529-558 (2011).

10. Liu H, Ding X, Zhou G, Li P, Wei X, Fan Y. Electrospinning of nanofibers for tissue engineering applications. J. Nanomater. 2013, 1-11 (2013).

- $\quad$ Excellent electrospinning review

11. Dvir T, Timko BP, Kohane DS, Langer R. Nanotechnological strategies for engineering complex tissues. Nat. Nanotechnol. 6(1), 13-22 (2011).

12. Sill TJ, von Recum HA. Electrospinning: Applications in drug delivery and tissue engineering. Biomaterials. 29(13), 1989-2006 (2008).

- Interesting electrospinning review

13. Pham QP, Sharma U, Mikos AG. Electrospinning of polymeric nanofibers for tissue engineering applications: a review. Tissue Eng. 12(5), 1197-211 (2006).

14. Vasita R, Katti DS. Nanofibers and their applications in tissue engineering. Int. J. Nanomedicine. 1 (1), 15-30 (2006)

15. Hartgerink JD, Beniash E, Stupp SI. Peptide-amphiphile nanofibers: a versatile scaffold for the preparation of self assembling materials. Proc. Natl. Acad. Sci. USA. 99, 5133-8 (2002).

16. Woo KM, Chen VJ, Ma PX. Nano-fibrous scaffolding architecture selectively enhanced protein adsorption contributing to cell attachment. J. Biomed. Mater. 
Res. 67A, 531-537 (2003).

17. Ravichandran $\mathrm{R}, \mathrm{Ng} \mathrm{CC}$, Liao $\mathrm{S}$, et al. Biomimetic surface modification of titanium surfaces for early cell capture by advanced electrospinning. Biomed. Mater. 7(1), 015001 (2011).

18. Gugutkov D, Gustavsson J, Ginebra MP, Altankov G. Fibrinogen nanofibers for guiding endothelial cell behavior. Biomater. Sci. 1(10), 1065 (2013).

Demonstrated that proteins are difficult to electrospun

19. Zeng J, Chen X, Xu X, et al. Ultrafine fibers electrospun from biodegradable polymers. J. Appl. Polym. Sci. 89(4), 1085-1092 (2003).

20. Lee SJ, Oh SH, Liu J, Soker S, Atala A, Yoo JJ. The use of thermal treatments to enhance the mechanical properties of electrospun poly(e-caprolactone) scaffolds. Biomaterials. 29(10), 1422-1430 (2008).

21. Keun Kwon I, Kidoaki S, Matsuda T. Electrospun nano- to microfiber fabrics made of biodegradable copolyesters: Structural characteristics, mechanical properties and cell adhesion potential. Biomaterials. 26(18), 3929-3939 (2005).

19. Mukhatyar VJ, Salmerón-Sánchez M, Rudra S, et al. Role of fibronectin in topographical guidance of neurite extension on electrospun fibers. Biomaterials. 32(16), 3958-3968 (2011).

20. Kim J-E, Noh K-T, Yu H-S, Lee H-Y, Jang J-H, Kim H-W. A fibronectin peptidecoupled biopolymer nanofibrous matrix to speed up initial cellular events. Adv. Eng. Mater. 12(4), B94-B100 (2010).

- $\quad$ Coupled the cell adhesive domain of fibronectin on nanofibers

21. Regis S, Youssefian S, Jassal M, Phaneuf MD, Rahbar N, Bhowmick S. Fibronectin adsorption on functionalized electrospun polycaprolactone scaffolds: Experimental and molecular dynamics studies. J. Biomed. Mater. Res. - Part A. 102(6), 1697-1706 (2014).

22. Zhang Y, Ouyang H, Chwee TL, Ramakrishna S, Huang ZM. Electrospinning of gelatin fibers and gelatin/PCL composite fibrous scaffolds. J. Biomed. Mater. Res. - Part B Appl. Biomater. 72(1), 156-165 (2005).

23. Khadka DB, Haynie DT. Protein- and peptide-based electrospun nanofibers in medical biomaterials. Nanomedicine Nanotechnology, Biol. Med. 8(8), 1242-1262 (2012).

- A review on electrospun fibrillar proteins

24. Yin A, Zhang K, McClure MJ, et al. Electrospinning collagen/chitosan/poly(Llactic acid-co- $\varepsilon$-caprolactone) to form a vascular graft: Mechanical and biological characterization. J. Biomed. Mater. Res. Part A 101A(5), 1292-1301 (2013).

25. Pereira M, Rybarczyk BJ, Odrljin TM, Hocking DC, Sottile J, Simpson-Haidaris PJ. The incorporation of fibrinogen into extracellular matrix is dependent on active assembly of a fibronectin matrix. J. Cell Sci. 115(Pt 3), 609-617 (2002).

26. Gugutkov D, Gustavsson J, Cantini M, Salmeron-Sánchez M, Altankov G. Electrospun fibrinogen-PLA nanofibres for vascular tissue engineering. J. Tissue Eng. Regen. Med. 4(7), In press (2016).

27. Grinnell F. Focal adhesion sites and the removal of substratum-bound fibronectin. J. Cell Biol. 103(6 II), 2697-2706 (1986).

28. Hubbell JA. Materials as morphogenetic guides in tissue engineering. Curr. Opin. Biotechnol. 14(5), 551-558 (2003).

29. Théry M, Pépin A, Dressaire E, Chen Y, Bornens M. Cell distribution of stress fibres in response to the geometry of the adhesive environment. Cell Motil. Cytoskeleton. 63(6), 341-355 (2006).

30. Wade RJ, Burdick JA. Engineering ECM signals into biomaterials. Mater. Today. 
15(10), 454-459 (2012).

-. A comprehensive review on mimicking ECM structural and biologic features

31. Daley WP, Peters SB, Larsen M. Extracellular matrix dynamics in development and regenerative medicine. J. Cell Sci. 121(Pt 3), 255-64 (2008).

32. Fraioli R, Dashnyam K, Kim J-H, et al. Surface guidance of stem cell behavior: Chemically tailored co-presentation of integrin-binding peptides stimulates osteogenic differentiation in vitro and bone formation in vivo. Acta Biomater. 43, 269-281 (2016).

33. Deitzel J., Kleinmeyer J, Harris D, Beck Tan N. The effect of processing variables on the morphology of electrospun nanofibers and textiles. Polymer (Guildf). 42(1), 261-272 (2001).

34. Matsuzaka K, Walboomers F, Ruijter A, Jansen J a. Effect of microgrooved poly1-lactic (PLA) surfaces on proliferation, cytoskeletal organization, and mineralized matrix formation of rat bone marrow cells. Clin. Oral Implants Res. 11(4), 325333 (2000).

35. Chew SY, Wen J, Yim EKF, Leong KW. Sustained release of proteins from electrospun biodegradable fibers. Biomacromolecules. 6(4), 2017-2024 (2005).

-• Demonstrated preserved electrospun protein activity

36. Humphries JD, Byron A, Humphries MJ. Integrin ligands at a glance. J. Cell Sci. 119(19), 3901-3903 (2006).

37. Hu YH, Winn SR, Krajbich I, Hollinger JO. Porous polymer scaffolds surfacemodified with arginine-glycine-aspartic acid enhance bone cell attachment and differentiation in vitro. J. Biomed. Mater. Res. part A. 64A(3), 583-590 (2003).

38. Aota SI, Nomizu M, Yamada KM. The short amino acid sequence Pro-His-SerArg-Asn in human fibronectin enhances cell-adhesive function. J. Biol. Chem. 269(40), 24756-24761 (1994).

39. Benoit DSW, Anseth KS. The effect on osteoblast function of colocalized RGD and PHSRN epitopes on PEG surfaces. Biomaterials. 26(25), 5209-5220 (2005).

40. Mardilovich A, Craig JA, McCammon MQ, Garg A, Kokkoli E. Design of a novel fibronectin-mimetic peptide-amphiphile for functionalized biomaterials. Langmuir. 22(7), 3259-3264 (2006).

41. Agarwal R, González-García C, Torstrick B, Guldberg RE, Salmerón-Sánchez M, García AJ. Simple coating with fibronectin fragment enhances stainless steel screw osseointegration in healthy and osteoporotic rats. Biomaterials 63, 137-145 (2015).

42. Cutler SM, García AJ. Engineering cell adhesive surfaces that direct integrin $\alpha 5 \beta 1$ binding using a recombinant fragment of fibronectin. Biomaterials. 24(10), 17591770 (2003).

- $\quad$ First use of cell adhesive domain of fibronectin on biomaterials

43. Ku Y, Chung CP, Jang JH. The effect of the surface modification of titanium using a recombinant fragment of fibronectin and vitronectin on cell behavior. Biomaterials. 26(25), 5153-5157 (2005).

44. Petrie TA, Capadona JR, Reyes CD, García AJ. Integrin specificity and enhanced cellular activities associated with surfaces presenting a recombinant fibronectin fragment compared to RGD supports. Biomaterials. 27(31), 5459-5470 (2006).

45. Wozniak M a, Modzelewska K, Kwong L, Keely PJ. Focal adhesion regulation of cell behavior. Biochim. Biophys. Acta. 1692(2-3), 103-19 (2004).

46. Kim T Il, Jang JH, Chung CP, Ku Y. Fibronectin fragment promotes osteoblastassociated gene expression and biological activity of human osteoblast-like cell. Biotechnol. Lett. 25(23), 2007-2011 (2003). 
47. Moursi AM, Globus RK, Damsky CH. Interactions between integrin receptors and fibronectin are required for calvarial osteoblast differentiation in vitro. J. Cell Sci. 110, 2187-2196 (1997).

48. Martino MM, Mochizuki M, Rothenfluh DA, Rempel SA, Hubbell JA, Barker TH. Controlling integrin specificity and stem cell differentiation in $2 \mathrm{D}$ and 3D environments through regulation of fibronectin domain stability. Biomaterials 30(6), 1089-1097 (2009).

49. Martino MM, Hubbell JA. The 12th-14th type III repeats of fibronectin function as a highly promiscuous growth factor-binding domain. FASEB J. 24(12), 47114721 (2010).

50. Lord MS, Foss M, Besenbacher F. Influence of nanoscale surface topography on protein adsorption and cellular response. Nano Today. 5(1), 66-78 (2010).

51. Dalby MJ, Gadegaard N, Tare R, et al. The control of human mesenchymal cell differentiation using nanoscale symmetry and disorder. Nat. Mater. 6(5), 407-413 (2007).

52. Mendonça G, Mendonça DBS, Simões LGP, et al. The effects of implant surface nanoscale features on osteoblast-specific gene expression. Biomaterials. 30(25), 4053-4062 (2009).

53. Komori T. Regulation of bone development and maintenance by Runx2. Front. Biosci. 13(13), 898 (2008).

54. Komori T. Regulation of Osteoblast Differentiation by Runx2. In: Advances in Experimental Medicine and Biology. 658, 43-49 (2009).

\section{Tables}

Table 1. Attachment stability of deposited (control and plasma activated) and covalently attached (plasma + APTES) nanofibers on Ti surfaces. The time (min) of detachment was evaluated with samples placed in an ultrasound bath.

\section{PLA CAS/PLA}




\begin{tabular}{ccc}
\hline Control & $9.5 \pm 4.5 \mathrm{~min}$ & $>20 \mathrm{~min}$ \\
Plasma & $14 \pm 1 \mathrm{~min}$ & $>20 \mathrm{~min}$ \\
Plasma + APTES & $>20 \mathrm{~min}$ & $>20 \mathrm{~min}$ \\
\hline
\end{tabular}

\section{Figure captions}

Fig.1 Low and high magnification SEM micrographs of PLA (A, B) and CAS/PLA (C, D) NFs and calculated NFs diameters (E). Bimodal distribution of NFs diameter was observed in CAS/PLA NFs as shown in (D) and quantified in (E). Scale bar denotes 10 $\mu \mathrm{m}$ in low magnification images and $1 \mu \mathrm{m}$ in high magnification images. 
Fig. 2 White light interferometer 3D-reconstructued micrographs and roughness average (Ra) of plain Ti and PLA and CAS/PLA NFs.

Fig. 3 Presence of CAS in CAS/PLA hybrid nanofibers. Fluorescence images of CAS integration in PLA (A) and CAS/PLA nanofibers (B) after staining CAS with Atto 550 NHS ester. Fluorescence images of superficial CAS availability on the PLA (C) and CAS/PLA (D) nanofibers after immunostaining with fibronectin antibody. Scale bar denotes $10 \mu \mathrm{m}$.

Fig. 4 Cumulative fluorescence signal due to the release of Atto 550 labeled CAS from CAS/PLA nanofibers in cell culture medium during 1, 3 and 7 days.

Fig. 5 Osteoblast-like cell adhesion on PLA or CAS/PLA nanofibers electrospun on plain Ti after $4 \mathrm{~h}$ of cell culture. No differences on cell number (A) were observed between the different surfaces. The area of cells (B) increased in presence of PLA NFs compared to plain $\mathrm{Ti}$, presenting highest values for CAS/PLA hybrid NFs. Symbol * indicates statistically significant differences $(\mathrm{P}<0.05)$ between conditions. Representative fluorescence images of phalloidin-stained cells cultured on bare Ti (C) and PLA (D) and CAS/PLA (E) nanofibers (10x). High magnification fluorescence images (40x) showing formation of actin filaments in cells cultured on PLA NFs $(G)$, specially on CAS/PLA hybrid NFs $(\mathrm{H})$, compared to plain Ti $(\mathrm{F})$. Scale bars denote $50 \mu \mathrm{m}$.

Fig. 6 Cell proliferation (A) and cell differentiation (B) of SaOS-2 cells cultured on Ti or PLA and CAS/PLA nanofibers during 3, 7, 14 and 21 days. At each time point, letter "a" indicates statistically significant differences compared to plain Ti ("a" corresponds to P $<0.05$ and "aa" corresponds to $\mathrm{P}<0.01$ ) and letter "b" indicates statistical significant differences compared to PLA NFs ("b" corresponds to $\mathrm{P}<0.05$ and "bb" corresponds to $\mathrm{P}<0.01)$. 


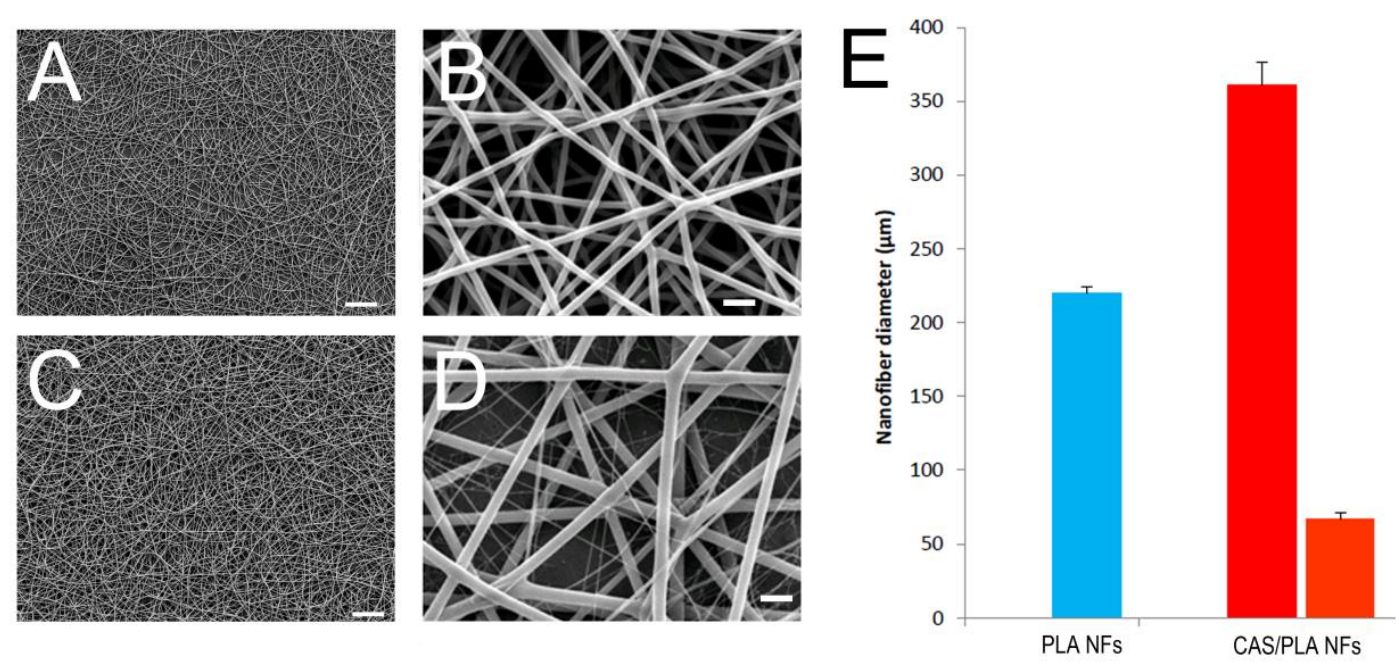

Fig. 1 


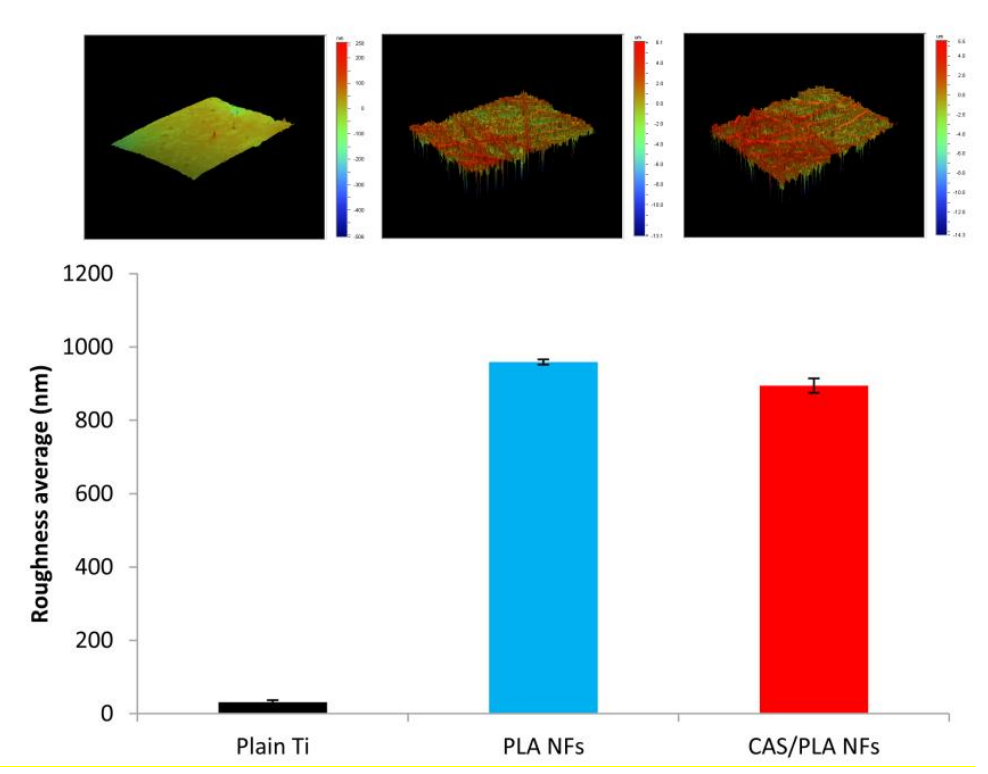

Fig. 2

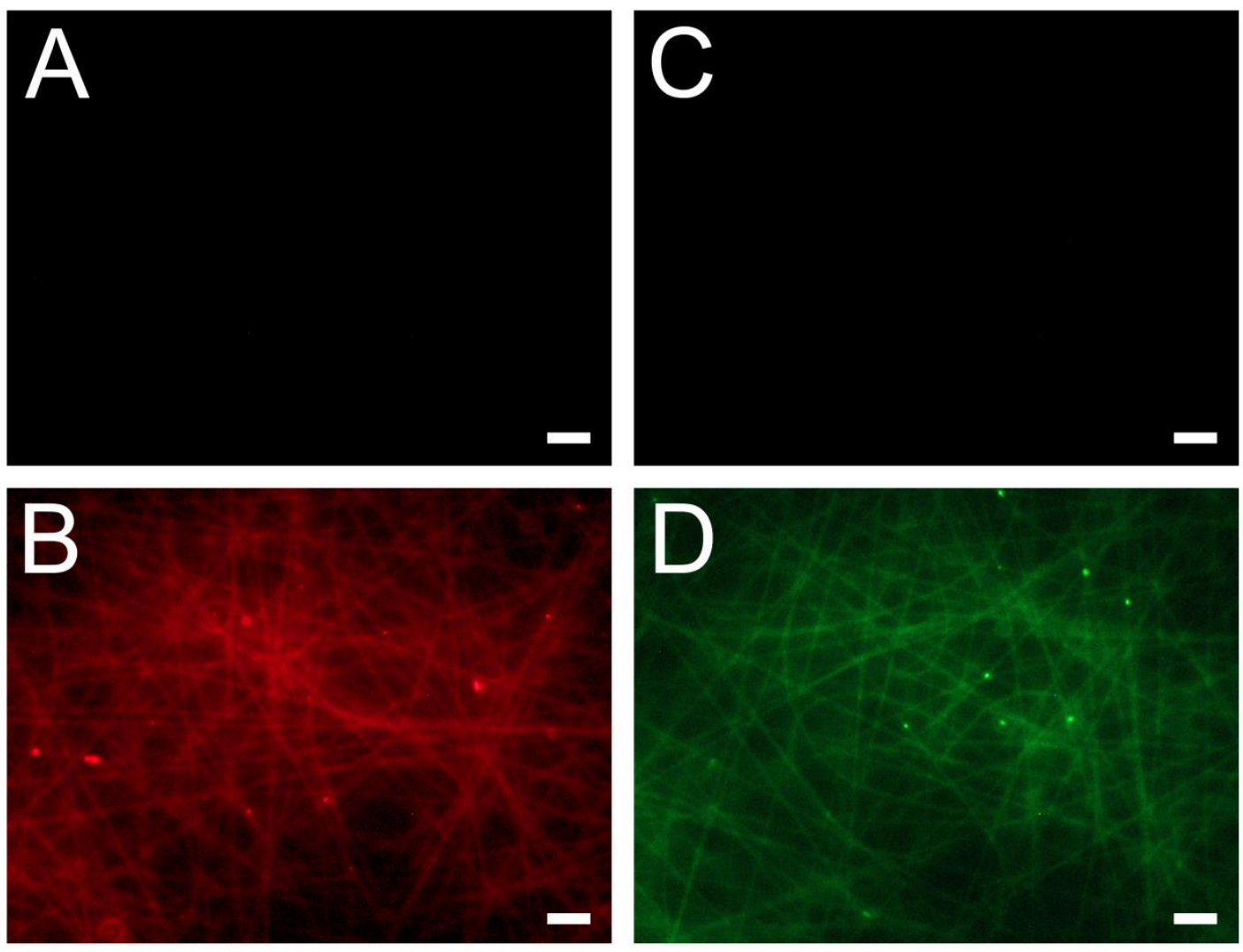


Fig. 3

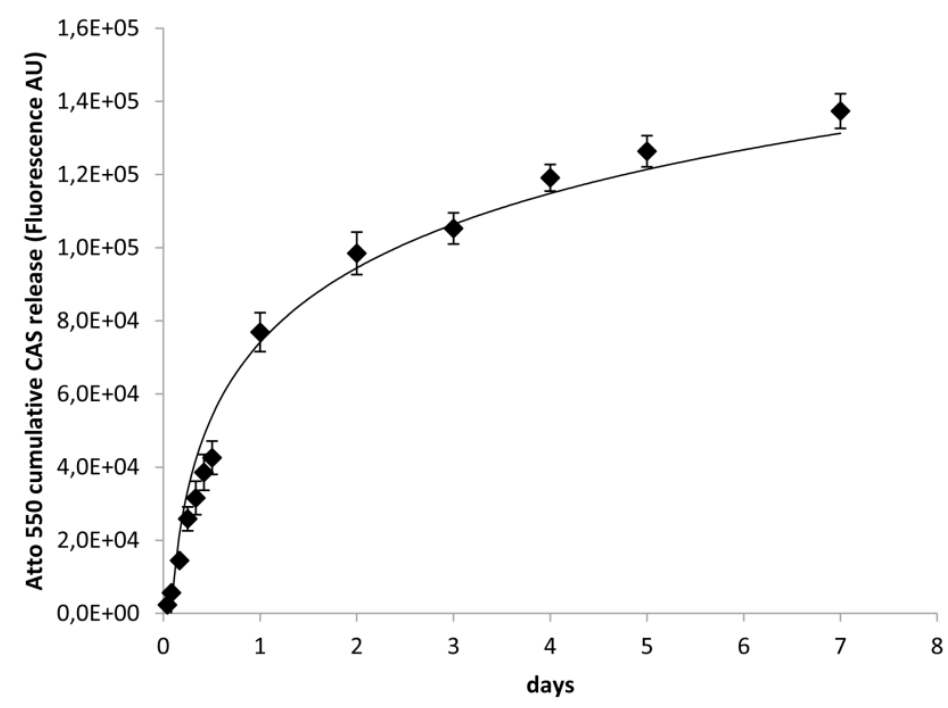

Fig. 4 

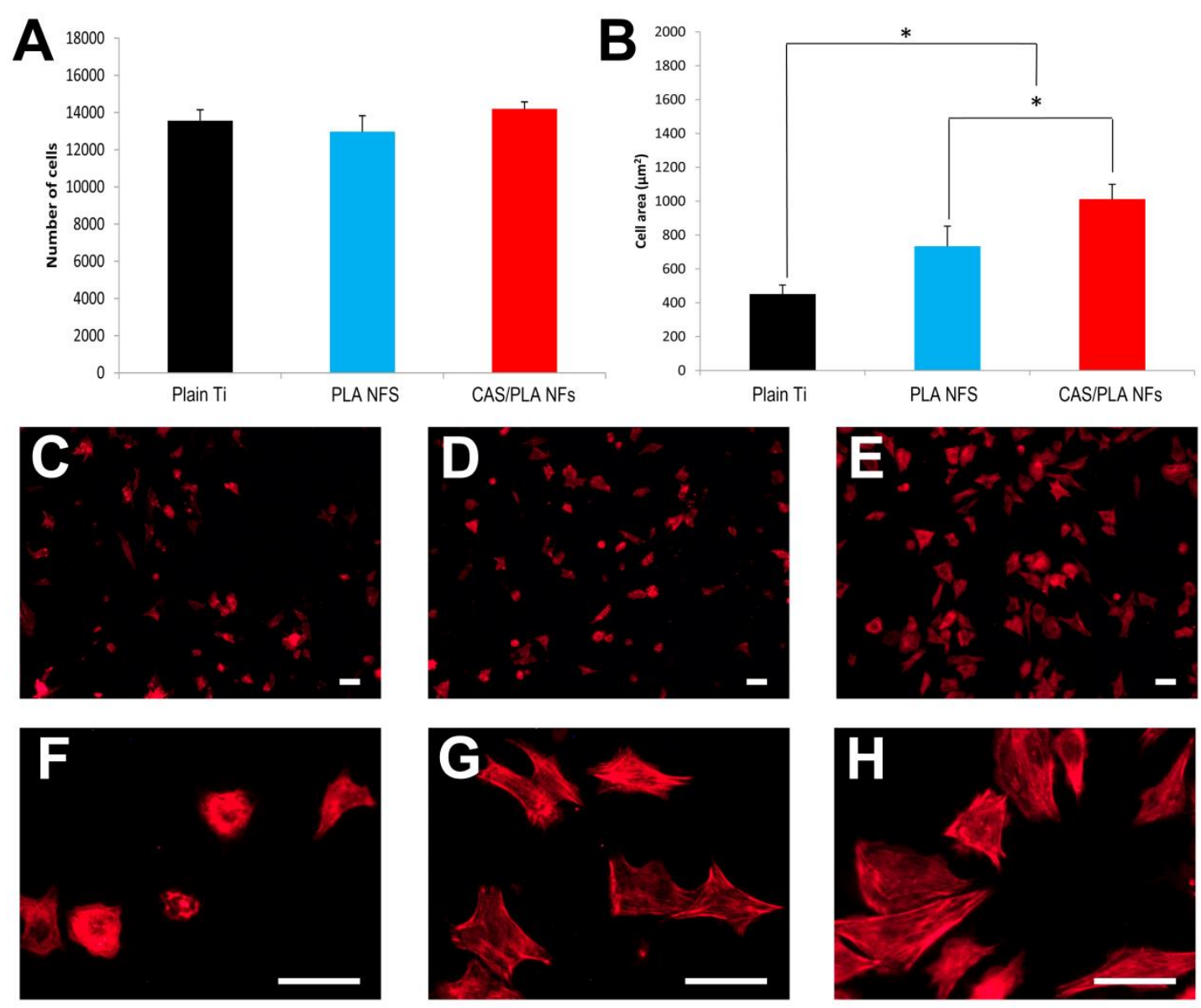

Fig. 5 



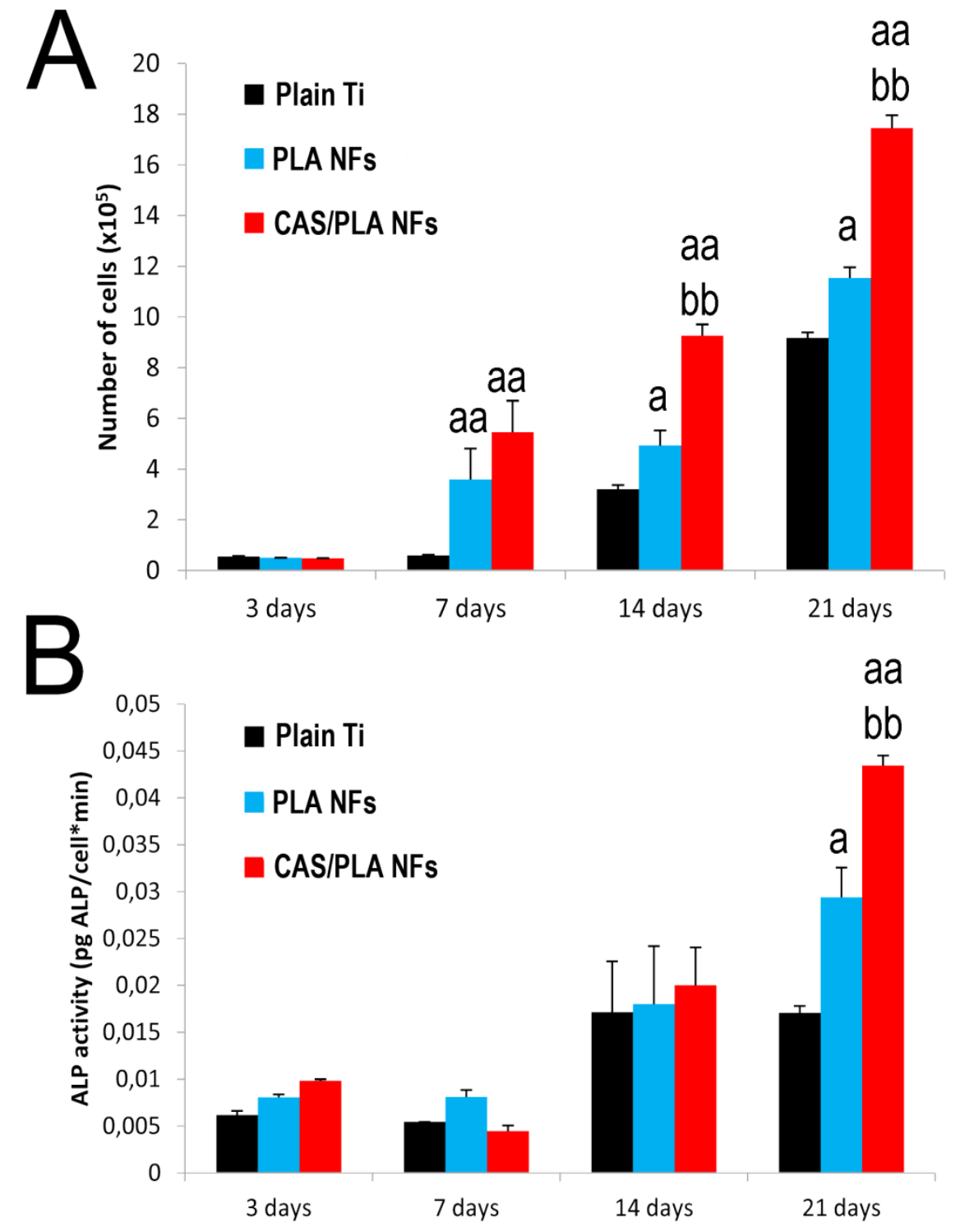

Fig. 6 